\title{
A convenient synthesis of cyclopenta[b]pyridin-2,5-dione as a non- glycosidic cardiotonic agent
}

\author{
Nicolas Robert, Cécile Verrier, Christophe Hoarau, Sylvain Célanire, \\ and Francis Marsais* \\ UMR 6014 - CNRS, INSA and University of Rouen \\ IRCOF - INSA of Rouen BP 0876131 Mont-Saint-Aignan Cédex, France \\ E-mail:francis.marsais@insa-rouen.fr
}

\section{Dedicated to Professor Guy Quéguiner on the occasion of his 70th birthday}

\begin{abstract}
A straightforward synthesis of cyclopenta[b]pyridin-2,5-dione is reported starting from the commercially available 2-bromo-6-methoxypyridine. The overall route consists in a first sequence of regioselective ortho lithiation and methoxycarbonylation followed by Heck vinylation, alkene reduction, cyclization and decarboxylation.
\end{abstract}

Keywords: Lithiation, Heck vinylation, pyridine, cyclopenta $[b]$ pyridine-2,5-dione

\section{Introduction}

A recent pharmacological evaluation of various functionalized 2-pyridones as cardiotonic agents has revealed that the cyclopenta[b]pyridin-2,5-dione (1) displays a high activity rather similar to Milrinone (2) which is the most effective non glycosidic cardiotonic agent clinically used for the treatment of severe heart failure. ${ }^{1}$ Cyclopenta[ $\left.b\right]$ pyridin-2,5-dione (1) constitutes also an interesting tensor of pharmaceutics exemplified by the antibacterial product $\mathbf{5}$ and a buildingblock for the access to 2-cyclopenta[b]pyridin-5-one (3) as seco analogues of 8-azasteroids (4). ${ }^{2}$

\section{Results and Discussion}

Despite the fact that the cyclopenta[b]pyridin-2,5-dione (1) is gaining interest as biologically active compounds and valuable building-blocks only two methods of preparation could be found in the literature. The first synthesis of cyclopenta[b]pyridin-2,5-dione (1) was first reported in 1954 (6 steps synthesis and a $13 \%$ overall yield). ${ }^{3}$ Mosti and his team published in 2003 a novel 
synthetic route based upon a one-pot and two-step construction of the 2-pyridone ring from the cyclopenta-1,3-dione. ${ }^{1}$ We recently described a novel synthesis of 6-methyl cyclopenta[b]pyridin-5-one (8) based on Heck vinylation of 2-bromo-6-methyl nicotinate (6) with methacrylate affording the pyridylacrylate intermediate 7, alkene reduction and Dieckmann condensation as depicted in Scheme $1{ }^{4}$ We wish to report here our results on the application of the latter method to the preparation of the cyclopenta $[b]$ pyridin-2,5-dione (1). Our retrosynthetic analysis suggests that 2-bromo-6-methoxynicotinate (10) could be a valuable precursor for this purpose (scheme 1). The pyridylacrylate 9 could be first prepared by Heck vinylation of bromopyridine 10. The expected cyclopenta[b]pyridin-2,5-dione (1) would be then obtained by reduction of the alkene followed by a cyclization-decarboxylation sequence. The success of this novel approach mainly depends on the access to the unknown 2-bromo-6-methoxynicotinate $\mathbf{1 0}$. Two possible routes could be designed: (i) the regioselective displacement of a bromine atom at position 2 of the methyl 2,6-dibromonicotinate (11) which could be readily prepared in two steps from the 2,6-dichloronicotinic acid by bromination and esterification ${ }^{7}$ or (ii), the regioselective methoxycarbonylation of the commercially available 2-bromo-6-methoxypyridine (12).<smiles>O=C1CCc2[nH]c(=O)ccc21</smiles>

1<smiles>Cc1[nH]c(=O)c(-c2ccncc2)cc1C#N</smiles>

2 Milrinone<smiles>O=C1CCc2nc(-c3cc[R1]cc3)ccc21</smiles>

3<smiles>O=C1CCC2=C1CC=C1c3cc[R]#cc3CCN12</smiles>

4<smiles>COc1ccc2c(n1)CC(=C(C)C[C@H]1OC[C@H](C[C@H]3O[C@H]3[C@H](C)[C@H](C)O)[C@@H](O)[C@@H]1O)C2=O</smiles>

\section{Figure 1}



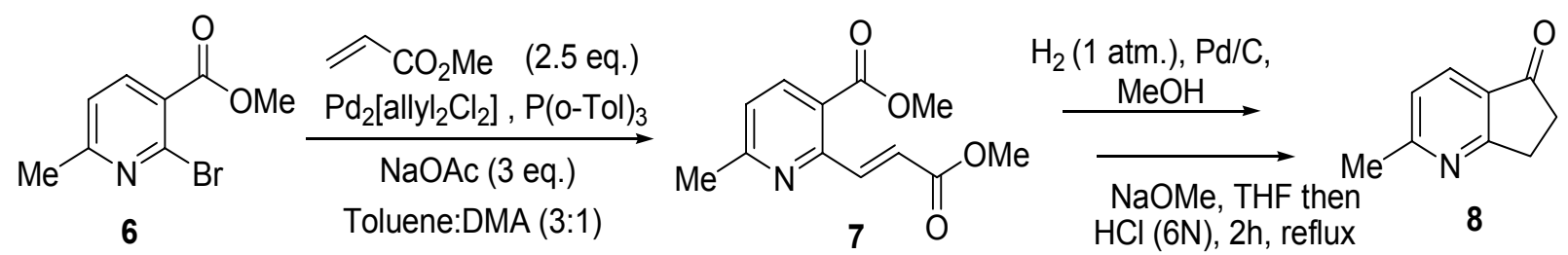<smiles>O=C1CCc2[nH]c(=O)ccc21</smiles>

1<smiles>C=CCOc1ccc(C(=O)OC)c(/C=C/C(=O)OC)n1</smiles>

9<smiles>C=CCOc1ccc(C(=O)OC)c(Br)n1</smiles>

10 (i)<smiles>COC(=O)c1ccc(Br)nc1Br</smiles>

Scheme 1. Previously reported synthesis of 6-methylcyclopenta[b]pyridine-5-one (8) and retrosynthetic analysis of cyclopenta[b]pyridin-2,5-dione (1).

We first attempted to displace the bromine atom at position 2 of ethyl 2,6-dibromonicotinate (11) with sodium methoxide. Treatment of 11 with 1.5 equivalent of sodium methoxide was carried out in refluxing $\mathrm{MeOH}$ for $24 \mathrm{~h}$ following the Hirokawa's protocol. ${ }^{5}$ A complete conversion of the starting material was observed and a mixture of 2- and 6- monosubstituted products 10 and 14 in a 7:3 ratio $\left({ }^{1} \mathrm{H}\right.$ NMR) could be obtained in $75 \%$ yield. Unfortunately, the two regioisomers $\mathbf{1 0}$ and $\mathbf{1 4}$ could not be separated by chromatography. Moreover, replacement of sodium methoxide by potassium methoxide also led to a 1:1 mixture regioisomers $\mathbf{1 0}$ and $\mathbf{1 4}$.<smiles>COC(=O)c1ccc(Br)nc1Br</smiles>

11<smiles>COC(=O)c1ccc(OC)nc1Br</smiles>

10<smiles>COC(=O)c1ccc(Br)nc1OC</smiles>

14

Scheme 2. Reagents and conditions: (i) $\mathrm{MeONa}$ (1 equiv.), $\mathrm{MeOH}$, reflux, 24h, 75\%.

We then shifted to the second route based on the regioselective methoxycarbonylation at position 3 of 2-bromo-6-methoxy pyridine (12). To this purpose, we first examined the lithiation of 2-bromo-6-methoxy pyridine (12) by treatment with hard bases such as lithium amides in THF before quenching the lithio intermediates with $\mathrm{D}_{2} \mathrm{O}$ (Table 1). A first set of lithiation experiments was achieved using 2,2',6,6'-tetramethylpiperidinyl-lithium (LTMP) at $-78^{\circ} \mathrm{C}$ (entries 1-3). 
Table 1. Assays of regioselective lithiation of $\mathbf{1 2}$ with lithium amides

\begin{tabular}{|c|c|c|c|c|c|}
\hline & 12 & & $15 a$ & & $15 b$ \\
\hline Entry & Base & Equiv. & $\mathrm{T}\left({ }^{\circ} \mathrm{C}\right)$ & $15 \mathbf{a}(\%)^{\mathrm{a}}$ & $15 b(\%)^{a}$ \\
\hline 1 & & 1 & $-78^{\circ} \mathrm{C}$ & - & - \\
\hline 2 & LTMP & 2 & -78 & 0 & 64 \\
\hline \multirow[t]{2}{*}{3} & & 3 & ${ }^{\circ} \mathrm{C}$ & 10 & 80 \\
\hline & & & $-78^{\circ} \mathrm{C}$ & & \\
\hline 4 & & 2 & -78 & 15 & - \\
\hline \multirow[t]{2}{*}{5} & LDA & 3 & ${ }^{\circ} \mathrm{C}$ & 15 & - \\
\hline & & & $-78^{\circ} \mathrm{C}$ & & \\
\hline 6 & & 2 & -50 & 22 & 12 \\
\hline \multirow[t]{2}{*}{7} & & 3 & ${ }^{\circ} \mathrm{C}$ & 20 & 11 \\
\hline & & & $-50^{\circ} \mathrm{C}$ & & \\
\hline
\end{tabular}

${ }^{\mathrm{a}}$ The ratio was determined by ${ }^{1} \mathrm{H}$ NMR spectroscopy

No deuterated product was obtained using 1 equivalent of LTMP whereas the 5-deuterated compound 15b was selectively formed in 64\% yield using 2 equivalents of LTMP. The starting material conversion could be significantly improved employing 3 equivalents of LTMP leading to a mixture of 3-and 5-deuterated products $(\mathbf{1 5 a}, \mathbf{1 5 b})$ in 2:8 ratio in favor of the $\mathbf{1 5 b}$ isomer. The less hard lithium diisopropylamine (LDA) was also checked (entries 4-7). Treatment of 12 with 2 equivalents of LDA followed by $\mathrm{D}_{2} \mathrm{O}$ trapping specifically provided the 3-deuterated product 15a in $15 \%$ yield (entry 4 ). This result could be related to the higher acidity of the proton at position 3. Surprisingly, we observed that the yield of 3-deuterated compound 15a was not improved using 3 equivalents of LDA at the same temperature (entry 5). Moreover warming the 3-lithio anion from $-78^{\circ} \mathrm{C}$ to $-50{ }^{\circ} \mathrm{C}^{6}$ before trapping with $\mathrm{D}_{2} \mathrm{O}$ afforded a mixture of $\mathbf{1 5 a}$ and 15b (entries 6,7).

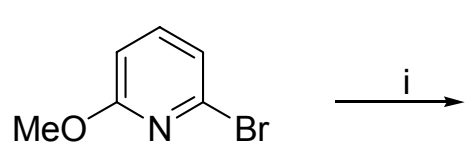

12<smiles>COc1ccc(C(=O)O)c(Br)n1</smiles>

16<smiles>COC(=O)c1ccc(OC)nc1Br</smiles>

10

Scheme 3. Reagents and conditions: (i) (a) LDA (2 equiv.), $-78^{\circ} \mathrm{C}$, THF, $1 \mathrm{~h}$, (b) solid carbon dioxide, (c) $\mathrm{HCl}(2 \mathrm{M}), 13 \%$; (ii) (a) $(\mathrm{COCl})_{2}$, DMFcat., (b) $\mathrm{MeOH}, 92 \%$. 
The 3-lithio anion formed by treatment of 12 with 2 equivalents of LDA at $-78^{\circ} \mathrm{C}$ in THF (table 1-entry 4) did not react with methyl cyanoformate but could be trapped by carbon dioxide to give the 3-bromo-6-methoxynicotinic acid (16) after acidic treatment. Acid (16) was isolated in $13 \%$ yield but the unreacted starting material 12 could be was readily recovered and re-used. Finally 16 was obtained in $41 \%$ overall yield after five lithiation-carboxylation sequences. Esterification of 16 gave the expected methyl 2-bromo-6-methoxy nicotinate (10) in $92 \%$ yield.

Heck vinylation of $\mathbf{1 0}$ with methyl acrylate using the $\eta^{3}$-allylpalladium chloride dimer with $\mathrm{P}(o-\mathrm{Tol})_{3}$ complex as catalyst in toluene and dimethylacetamide (DMA) as co-solvent ${ }^{4}$ provided the $\beta$-2-pyridyl acrylate 9 in an excellent $82 \%$ yield. The use of DMA is a crucial parameter as the vinylation of $\mathbf{1 0}$ failed without this co-solvent. Reduction of the alkene under soft conditions provided diester 17 which could be cyclized by a Dieckmann condensation with sodium methoxide to methyl cyclopenta[b]pyridine-5-one-6-carboxylate (18) in 70\% overall yield. Finally, treatment with hydrochloric acid allows hydrolysis, decarboxylation and demethylation of 18 to give cyclopenta[c]pyridine-2,5-dione (1) in $84 \%$ yield.<smiles>CCCc1nc(OC)ccc1C(=O)OC</smiles>

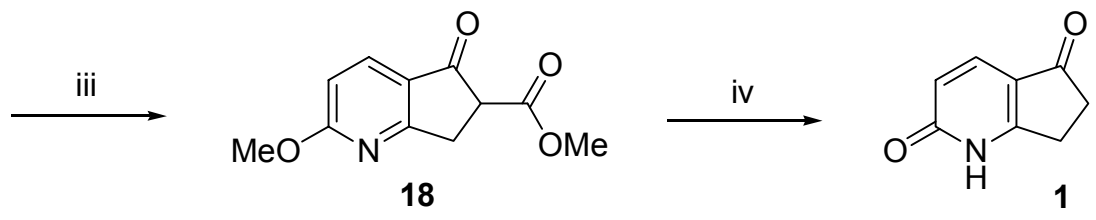

Scheme 4. Reagents and conditions: (i) methyl acrylate (2.5 equiv.), $\mathrm{Pd}_{2}\left[\mathrm{allyl}_{2} \mathrm{Cl}_{2}\right], \mathrm{P}(o-\mathrm{Tol})_{3}$, $\mathrm{NaOAc}$ (3 equiv.), toluene: DMA (3:1), 92\%; (ii) $\mathrm{H}_{2}$ (1 atm), $\mathrm{Pd} / \mathrm{C}$ (10 mol \%), $\mathrm{MeOH}$, r.t., 2h, 93\%; (iii) NaOMe, THF, reflux, 2h, 75\%; (iv) $\mathrm{HCl}$ (5 M), reflux, 3h, 84\%.

\section{Conclusions}

A convenient route to cyclopenta[b]pyridin-2,5-dione (1) is reported starting from methyl 2bromo-6-methoxynicotinate (10) through a 4 steps synthesis, vinylation, alkene reduction and cyclization-decarboxylation, in $48 \%$ overall yield. Two routes were studied for the previous preparation of the parent methyl 2-bromo-6-methoxynicotinate (10). Regioselective displacement of the bromine atom of methyl 2,6-dibromonicotinate (11) by the sodium or potassium methoxide could not be applied leading to a mixture of regioisomers which could not be separated by chromatography. The second approach was based upon the regioselective 
carboxylation of the commercially available 2-bromo-6-methoxypyridine (12) at position 3 of the pyridine nucleus. The regioselective lithiation-carboxylation and esterification of 12 at position 3 was achieved using LDA at $-78^{\circ} \mathrm{C}$ in THF to give the expected methyl 2-bromo-6methoxynicotinate (10) in $12 \%$ yield in two steps.

\section{Experimental Section}

General Procedures. Tetrahydrofuran (THF), ether $\left(\mathrm{Et}_{2} \mathrm{O}\right)$ were pre-dried with pellets of $\mathrm{KOH}$ and distilled over sodium benzophenone ketyl under $\mathrm{Ar}$ before use. $\mathrm{CH}_{2} \mathrm{Cl}_{2}, \mathrm{NEt}_{3}$ and toluene were distilled from $\mathrm{CaH}_{2}$. Methanol and ethanol were distilled from magnesium turnings; dimethylacetamide was distilled over 4 A molecular sieves. For Flash chromatography, Merck silica gel (70-230 mesh) was used. The melting points were measured on a Kofler melting points apparatus and were not corrected. The ${ }^{1} \mathrm{H}$ NMR and ${ }^{13} \mathrm{C}$ NMR spectra were recorded with a Bruker Avance-300 spectrometer operating at $300 \mathrm{MHz}$. Commercially available starting materials were used without further purification. Infrared spectra were recorded on a PerkinElmer FT-IR 1650 spectrophotometer. Elemental analysis of compounds was carried out on a Carlo Erba 1160. Mass spectra were recorded on a JEOL JMS AX-500 spectrometer, in electronic impact (EI). The starting compound $\mathbf{1 2}$ is commercially available.

\section{Preparation of 6-methoxy-2-bromonicotinate (10)}

Methyl 2,6-dibromonicotinate (11). To a stirred solution of 2,6-dibromonicotinic acid ${ }^{7}$ (500 $\mathrm{mg}, 1.8 \mathrm{mmol})$ and 3 drops of DMF in dry $\mathrm{CH}_{2} \mathrm{Cl}_{2}(10 \mathrm{ml})$ was slowly added oxalyl chloride $(172 \mu \mathrm{L}, 2.0 \mathrm{mmol})$ at $0^{\circ} \mathrm{C}$. The mixture was stirred at room temperature for $1 \mathrm{~h}$ and solvents were removed in vacuo. To the crude product was added dry methanol $(10 \mathrm{ml})$ at $0{ }^{\circ} \mathrm{C}$ and the resulting solution was stirred for $2 \mathrm{~h}$ at room temperature. Methanol was removed in vacuo and the crude solid was dissolved in $\mathrm{CH}_{2} \mathrm{Cl}_{2}(10 \mathrm{ml})$. The $\mathrm{pH}$ of the aqueous layer was then adjusted to 7 by adding aq. $\mathrm{K}_{2} \mathrm{CO}_{3}(2 M)$. The separated organic layer was washed three times with water, dried $\left(\mathrm{MgSO}_{4}\right)$ and concentrated in vacuo to give 11 (488 mg, $92 \%$ yield) as beige powder, $\mathrm{mp}$

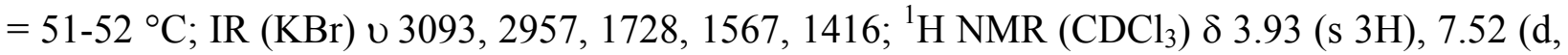
$1 \mathrm{H}, J=8.1 \mathrm{~Hz}), 7.93\left(\mathrm{~d}, 1 \mathrm{H}, J=8.1 \mathrm{~Hz} ;{ }^{13} \mathrm{C} \mathrm{NMR}\left(\mathrm{CDCl}_{3}\right) \delta 53.5,127.3,128.7,140.4,141.7\right.$, 143.9, 165.0; Anal. Calcd for $\mathrm{C}_{7} \mathrm{H}_{5} \mathrm{Br}_{2} \mathrm{NO}_{2}$ (294.9): C, 28.51; H, 1.71; N, 4.75. Found: C, 29.01; H, $1.67 ; \mathrm{N}, 4.71 \%$.

Procedure for nucleophilic substitution using sodium methoxide. To a stirred solution of methyl 2,6-dibromonicotinate $(\mathbf{1 1}, 1.5 \mathrm{~g}, 5.0 \mathrm{mmol})$ in dry $\mathrm{MeOH}(20 \mathrm{ml})$ was added $\mathrm{NaOMe}$ $(270 \mathrm{mg}, 5.0 \mathrm{mmol})$. The mixture was refluxed for $24 \mathrm{~h}$ and then poured into cold aq. $\mathrm{NaHCO}_{3}$ $(5 \%, 50 \mathrm{ml})$ and the product was extracted with ether $(3 \times 20 \mathrm{~mL})$. The separated organic phase was separated and concentrated in vacuo. Ether $(40 \mathrm{~mL})$ was added to the crude liquid and the organic phase was washed with brine $(40 \mathrm{~mL})$, dried $\left(\mathrm{MgSO}_{4}\right)$ and concentrated in vacuo. The 
crude product was purified by chromatography on silica gel $\left(\mathrm{CH}_{2} \mathrm{Cl}_{2}\right)$ to give a $(7: 3)$ mixture of 10 and 14 (923 mg, $75 \%$ ).

2-Bromo-6-methoxypyridine (12). To a stirred solution of 2,6-dibromopyridine (20 g, 84 $\mathrm{mmol})$ in dry $\mathrm{MeOH}(50 \mathrm{~mL})$ was added $\mathrm{NaOMe}(8 \mathrm{~g}, 148 \mathrm{mmol})$. The mixture was refluxed for $25 \mathrm{~h}$ and then poured into a cold aq. soln. of $\mathrm{NaHCO}_{3}(5 \%, 50 \mathrm{~mL})$. The product was extracted with ether $(3 \times 30 \mathrm{ml})$ and the combined organic layers were washed with brine $(40 \mathrm{ml})$ and concentrated in vacuo. The crude product was purified by chromatography on silica gel (EtOAc/Petrol 9:1) to give 12 (13 g, $83 \%$ ) as a liquid; bp=206-207 $\mathrm{C}$; IR (KBr) v 2953, 1596, 1582, 1558, 1472, 1413, 1298, 1022, 857; ${ }^{1} \mathrm{H}$ NMR $\left(\mathrm{CDCl}_{3}\right) \delta 3.93$ (s 3H), 6.69 (t, $1 \mathrm{H}, J=7.7$ $\mathrm{Hz}), 7.06$ (d, 1H, $J=7.7 \mathrm{~Hz}), 7.40$ (d, 1H, $J=7.7 \mathrm{~Hz})$.

2-Bromo-6-methoxynicotinic acid (16). To a stirred solution of LDA (106 mmol) in dry THF $(50 \mathrm{~mL})$ was added dropwise under $\mathrm{N}_{2}$ at $-78^{\circ} \mathrm{C}$ a solution of 2-bromo-6-methoxypyridine 12 $(10 \mathrm{~g}, 53 \mathrm{mmol})$ in dry THF $(50 \mathrm{ml})$. After stirring $1 \mathrm{~h}$. at the same temperature, the mixture was poured on an excess of carbonic dry ice. Solvents were removed in vacuo and the crude residue was dissolved in water $(30 \mathrm{ml})$. The separated aqueous layer was washed with $\mathrm{CH}_{2} \mathrm{Cl}_{2}(3 \times 15 \mathrm{ml})$ and $\mathrm{pH}$ was adjusted to 4 by adding aq. $\mathrm{HCl}(2 M)$. The product was extracted with $\mathrm{CH}_{2} \mathrm{Cl}_{2}(3 \times 15$ $\mathrm{ml})$ and the combined organic layers were washed with brine, dried $\left(\mathrm{MgSO}_{4}\right)$ and concentrated in vacuo to give $16(1.6 \mathrm{~g}, 13 \%)$ as a beige solid; $\mathrm{mp}=212-213^{\circ} \mathrm{C}$; IR $(\mathrm{KBr}) \vee 1302,1591,1693$, 2959, 3418; ${ }^{1} \mathrm{H}$ NMR $\left(\mathrm{CDCl}_{3}\right) \delta 3.89$ (s, 3H), 6.91 (d, 1H, J=8.4 Hz), 8.10 (d, 1H, $\left.J=8.4 \mathrm{~Hz}\right)$; ${ }^{13} \mathrm{C} \mathrm{NMR}\left(\mathrm{CDCl}_{3}\right) \delta 54.8,109.4,122.8,137.9,142.7,163.7,165.8$. Anal. Calcd for $\mathrm{C}_{7} \mathrm{H}_{6} \mathrm{BrNO}_{3}$ (232.0): C, 36.26; H, 2.61; N, 6.04. Found: C, 36.23; H, 2.67; N, $6.21 \%$.

Methyl 2-bromo-6-methoxynicotinate (10). To a stirred solution of 2-bromo-6methoxynicotinic acid $16(1 \mathrm{~g}, 4.3 \mathrm{mmol})$ and 3 drops of DMF in dry $\mathrm{CH}_{2} \mathrm{Cl}_{2}(20 \mathrm{ml})$ was slowly added oxalyl chloride $(462 \mu \mathrm{L}, 5.4 \mathrm{mmol})$ at $0^{\circ} \mathrm{C}$. The mixture was stirred at room temperature for $1 \mathrm{~h}$ and solvents were removed in vacuo. Dry methanol $(30 \mathrm{ml})$ was then added at $0^{\circ} \mathrm{C}$ and the resulting mixture was stirred for $2 \mathrm{~h}$ at room temperature. Methanol was removed in vacuo and $\mathrm{CH}_{2} \mathrm{Cl}_{2}(30 \mathrm{ml})$ was added. The organic phase was washed with water $(3 \times 15 \mathrm{ml})$, dried $\left(\mathrm{MgSO}_{4}\right)$ and concentrated in vacuo to give the ester 10 (973 mg, $\left.92 \%\right)$ as white solid, $\mathrm{mp}=54$ $55{ }^{\circ} \mathrm{C}$; IR $(\mathrm{KBr}) \vee 1247,1586,1724,2952 ;{ }^{1} \mathrm{H}$ NMR $\left(\mathrm{CDCl}_{3}\right) \delta 3.85(\mathrm{~s}, 3 \mathrm{H}), 3.93(\mathrm{~s}, 3 \mathrm{H}), 6.93$ $(\mathrm{d}, 1 \mathrm{H}, J=8.5 \mathrm{~Hz}), 7.99(\mathrm{~d}, 1 \mathrm{H}, J=8.5 \mathrm{~Hz}) ;{ }^{13} \mathrm{C} \mathrm{NMR}\left(\mathrm{CDCl}_{3}\right) \delta 42.5,54.7,109.3,121.1$, 139.7, 142.4, 164.5, 165.1; Anal. Calcd for $\mathrm{C}_{8} \mathrm{H}_{8} \mathrm{BrNO}_{3}$ (246.0): C, 39.05; H, 3.28; N, 5.69. Found: C, 39.11; H, 3.32; N, $5.71 \%$.

\section{Preparation of the cyclopenta[b]pyridin-2,5-dione (1)}

(E)-Methyl 6-methoxy-2-(3-methoxy-3-oxoprop-1-enyl)nicotinate (9). A degassed mixture of methyl 2-bromo-6-methoxynicotinate $(\mathbf{1 0}, 0.30 \mathrm{~g}, 1.2 \mathrm{mmol})$, methyl acrylate $(293 \mu \mathrm{l}, 3.3$ mmol), allylpalladium chloride dimer $\mathrm{Pd}_{2}\left(\operatorname{allyl}_{2} \mathrm{Cl}_{2}\right)(24 \mathrm{mg}, 0.065 \mathrm{mmol}), \mathrm{P}(o-\mathrm{Tol})_{3}(40 \mathrm{mg}$, $0.13 \mathrm{mmol}), \mathrm{Na}_{2} \mathrm{CO}_{3}(320 \mathrm{mg}, 3.0 \mathrm{mmol})$, toluene $(2.53 \mathrm{ml})$ and dimethyl acetamide DMA (0.84 $\mathrm{ml}$ ) was heated in a sealed tube at $115^{\circ} \mathrm{C}$ for $5 \mathrm{~h}$. The reaction mixture was filtrated though Celite and concentrated in vacuo. The residue was purified by chromatography on silica gel (EtOAc / 
Petrol 3:7) to give 9 (296 $\mathrm{mg}, 82 \%)$ as a yellow solid, $\mathrm{mp}=112-113^{\circ} \mathrm{C}$; IR (KBr) v 1132, 1243, 1482, 1589, 1737, 2961, 3012, 3097; ${ }^{1} \mathrm{H}$ NMR $\left(\mathrm{CDCl}_{3}\right) \delta 3.81(\mathrm{~s}, 3 \mathrm{H}), 3.90$ (s, 3H), 3.99 (s, 3H), $6.72(\mathrm{~d}, 1 \mathrm{H}, J=8.6 \mathrm{~Hz}), 7.11(\mathrm{~d}, 1 \mathrm{H}, J=15.2 \mathrm{~Hz}), 8.11(\mathrm{~d}, 1 \mathrm{H}, J=8.1 \mathrm{~Hz}), 8.57(\mathrm{~d}, 1 \mathrm{H}, J=15.2$ $\mathrm{Hz}) ;{ }^{13} \mathrm{C} \mathrm{NMR}\left(\mathrm{CDCl}_{3}\right) \delta$ 52.2, 52.8, 54.2, 112.4, 119.7, 125.2, 140.9, 141.8, 152.8, 164.9, 166.5, 167.6; Anal. Calcd for $\mathrm{C}_{12} \mathrm{H}_{13} \mathrm{NO}_{5}$ (251.2): C, 57.37; H, 5.22; N, 5.58. Found: C, 57.43; H, 5.34; $\mathrm{N}, 5.61 \%$.

Methyl 6-methoxy-2-(3-methoxy-3-oxopropyl)nicotinate (17). A degassed suspension of $10 \%$ $\mathrm{Pd} / \mathrm{C}(60 \mathrm{mg}, 0.06 \mathrm{mmol})$ in a solution of $9(150 \mathrm{mg}, 0.6 \mathrm{mmol})$ in $\mathrm{MeOH}(10 \mathrm{ml})$ was vigorously stirred for $3 \mathrm{~h}$ at room temperature under $\mathrm{H}_{2}$ (1 bar). The reaction mixture was filtered though a short pad of Celite and concentrated in vacuo to give 17 (141 mg, $93 \%$ ) as a yellow liquid; IR (KBr) v 1021, 1248, 1595, 1723, 2962; ${ }^{1} \mathrm{H}$ NMR $\left(\mathrm{CDCl}_{3}\right) \delta 2.77(\mathrm{t}, 2 \mathrm{H}, J=7.0 \mathrm{~Hz})$, $3.47(\mathrm{t}, 2 \mathrm{H}, J=7.0 \mathrm{~Hz}), 3.63(\mathrm{~s}, 3 \mathrm{H}), 3.83(\mathrm{~s}, 3 \mathrm{H}), 3.88(\mathrm{~s}, 3 \mathrm{H}), 6.53(\mathrm{~d}, 1 \mathrm{H}, J=8.7 \mathrm{~Hz}), 8.06$ (d, $1 \mathrm{H}, J=8.7 \mathrm{~Hz}) ;{ }^{13} \mathrm{C} \mathrm{NMR}\left(\mathrm{CDCl}_{3}\right) \delta 30.2,30.7,50.4,52.6,106.9,116.6,140.4,159.9$ ? 163.8, 165.5, 172.9; Anal. Calcd for $\mathrm{C}_{12} \mathrm{H}_{15} \mathrm{NO}_{5}$ (253.2): C, 56.91; H, 5.97; N, 5.53. Found: C, 56.75; H, 6.04; N, $5.66 \%$.

Methyl 2-methoxy-5-oxo-6,7-dihydro-5 $H$-cyclopenta[b]pyridine-6-carboxylate (18). Sodium methoxide $(81 \mathrm{mg}, 1.5 \mathrm{mmol})$ in THF $(5 \mathrm{ml})$ was added to a solution of $17(250 \mathrm{mg}, 1 \mathrm{mmol})$ in dry THF $(8 \mathrm{ml})$ under $\mathrm{N}_{2}$ and the mixture was refluxed for $2 \mathrm{~h}$. The $\mathrm{pH}$ was then adjusted to 5 by adding aq. $\mathrm{HCl}(2 M)$ before extraction of the product with $\mathrm{CH}_{2} \mathrm{Cl}_{2}(2 \times 15 \mathrm{ml})$. The combined organic layers was washed with aq. $\mathrm{Na}_{2} \mathrm{CO}_{3}(10 \%, 5 \mathrm{ml})$, sat. aq. $\mathrm{NH}_{4} \mathrm{Cl}(5 \mathrm{ml})$, dried $\left(\mathrm{MgSO}_{4}\right)$ and concentrated in vacuo. The crude product was purified by chromatography on silica gel (EtOAc / petrol 3:7) to give $18(166 \mathrm{mg}, 75 \%)$ as a beige solid, $\mathrm{mp}=81-82^{\circ} \mathrm{C}$; IR (KBr) $v 1021$, 1250, 1439, 1595, 1736, 2960; ${ }^{1} \mathrm{H}$ NMR $\left(\mathrm{CDCl}_{3}\right) \delta 3.29-3.31(\mathrm{~m}, 1 \mathrm{H}), 3.45-3.50(\mathrm{~m}, 1 \mathrm{H}), 3.70-$ $3.74(\mathrm{~m}, 1 \mathrm{H}), 3.73(\mathrm{~s}, 3 \mathrm{H}), 4.00(\mathrm{~s}, 3 \mathrm{H}), 6.68(\mathrm{~d}, 1 \mathrm{H}, J=8.7 \mathrm{~Hz}), 7.82(\mathrm{~d}, 1 \mathrm{H}, J=8.7 \mathrm{~Hz}) ;{ }^{13} \mathrm{C}$ NMR $\left(\mathrm{CDCl}_{3}\right) \delta 33.3,53.1,53.2,54.9,112.2,123.3,135.1,169.7,169.8,175.1,196.5$.

6,7-Dihydro-1H-cyclopenta[b]pyridine-2,5-dione (1). A solution of 18 (100 $\mathrm{mg}, 0.45 \mathrm{mmol})$ in aq. $\mathrm{HCl}(5 \mathrm{M}, 2 \mathrm{ml})$ was refluxed for $3 \mathrm{~h}$. The mixture was cooled to room temperature and the $\mathrm{pH}$ was adjusted to 5 by adding aq. $\mathrm{K}_{2} \mathrm{CO}_{3}(2 \mathrm{M})$. The product was extracted with EtOAc $(5 \times 15 \mathrm{~mL})$. The combined organic layers were dried $\left(\mathrm{MgSO}_{4}\right)$, concentrated in vacuo to give 1 (56 mg, $84 \%$ ) as a beige solid, $\mathrm{mp}>260^{\circ} \mathrm{C}$; IR $(\mathrm{KBr}) \vee 3085,2924,1675-1653,1427,1105 ;{ }^{1} \mathrm{H}$ NMR (DMSO) $\delta 2.56(\mathrm{~m}, 2 \mathrm{H}), 2.94(\mathrm{t}, 2 \mathrm{H}, J=5.1 \mathrm{~Hz}), 6.31(\mathrm{~d}, 1 \mathrm{H}, J=9.4 \mathrm{~Hz}), 7.58(\mathrm{~d}, 1 \mathrm{H}, J=$ $9.4 \mathrm{~Hz}$ ), 12.6 (s, 1H) ; ${ }^{13} \mathrm{C}$ NMR (DMSO) $\delta 24.5,34.7,116.3,119.2,134.1,164.1,169.5,199.3$; Anal. Calcd for $\mathrm{C}_{8} \mathrm{H}_{7} \mathrm{NO}_{2}$ (149.1): C, 64.43; H, 4.73; N, 9.39. Found: C, 64.42; H, 4.83; N, 9.23 $\%$. 


\section{References and Notes}

1. Fossa, P.; Menozzi, G.; Dorigo, P.; Floreani, M.; Mosti, L. Bioorg. Med. Chem. 2003, 11, 4749. The authors reported that cyclopenta[b]pyridin-2,5-dione is able to increase atrial contractility to an extent which is significantly higher than of Milrinone. Cyclopenta $[b]$ pyridin-2,5-dione is similar to Milrinone in its pharmacological action and in its activity. The positive inotropic effect exerted is related to an increase of cAMP levels obtained through inhibition of cGMP-inhibited cAMP phosphodiesterase (PDE) called Type 3 (PDE3). The maximal inhibition of cyclopenta[b]pyridin-2,5-dione against PDE3 being $81.93 \pm 0.29 \%$ versus $100 \%$ of Milrinone.

2. Prakash, H. S.; Senthilkumar, S. P. Curr. Org. Chem. 2004, 8, 1521.

3. Ramirez, F.; Paul, A. P. J. Org. Chem. 1954, 19, 183.

4. Robert, N.; Hoarau, C.; Célanire, S.; Ribéreau, P. ; Godard, A.; Guéguiner, G. ; Marsais, F. Tetrahedron 2005, 61, 4569.

5. Hirokawa and co-workers (Hirokawa, Y.; Horijawa, T.; Kato, S. Chem. Pharm. Bull. 2000, $48,1847-1853$ previously reported that the regioselective displacement of a chlorine from methyl 2,6-dichloronicotinate with sodium methoxide is more effective using $\mathrm{MeOH}$ as solvent leading to methyl 2-chloro-6-methoxychloroniconinate as the major isomer (7:3 ratio).

6. Above $-50^{\circ} \mathrm{C}$ the $\mathrm{C}-3$ lithio- anion was degraded.

7. Mutterer, F.; Weis, C.; Claus, D. Helv. Chim. Acta 1976, 59, 229. 